\title{
The Mechanism of Microcystis aeruginosa Death upon Exposure to Bacillus mycoides
}

Gumbo JR ${ }^{\mathrm{a}, \mathrm{b}^{*}}$ and Cloete $\mathrm{TE}^{\mathrm{a}, \mathrm{c}}$

${ }^{\mathrm{a}}$ Department of Microbiology \& Plant Pathology, University of Pretoria, 0001, South Africa.

${ }^{\mathrm{b}}$ Department of Hydrology and Water Resources, University of Venda, P/Bag x5050, Thohoyandou, 0950, South Africa.

${ }^{c}$ Faculty of Science, Stellenbosch University, P/Bag X1, Matieland, 7602

Tel: +27 21808 3071, Fax: + 2721808 3680, Email: eugenecloete@ sun.ac.za

\begin{abstract}
Electron microscopy observations revealed at least two mechanisms of $M$. aeruginosa cell death upon exposure to $B$. mycoides i.e. cell membrane lysis and shadowing of algal cells leading to photo-inhibition. There were ultra-structural changes that occurred in bacteria treated $M$. aeruginosa cells. SEM images showed swollen $M$. aeruginosa cells due to cell membrane damage and increased osmotic pressure. The production of intracellular stress related structures by $M$. aeruginosa indicated cell stress as a result of bacteria causing shadowing and photo - inhibition affecting the photosynthetic system. There is evidence, which showed that Bacillus mycoides B16 might be an ectoparasite during the lysis of Microcystis cells and exhibit multicellular forms that are Bdellovibriolike bacteria during the last stages lysis of Microcystis cells in order to survive an adverse external environment that was nutrient limited. The mechanism of cyanobacterial lysis may involve changes in ultrastructure of Microcystis aeruginosa, possibly affecting energy sources and the photosynthetic system after exposure to bacteria. This may lead to the death of the cyanobacteria after exhaustion of energy sources and loss of nutrients to the predator bacteria, B. mycoides B16. A better understanding of the interactions between $B$. mycoides 16 and $M$. aeruginosa is important for the development of a biological control agent and ultimately the management of harmful algal blooms dominated by $M$. aeruginosa.
\end{abstract}

Key words: Bacillus mycoides B16, mechanism of lysis, Microcystis aeruginosa, multicellular, photo-inhibition.

\section{Introduction}

Microcystis aeruginosa dominated harmful algal blooms (HAB) are on the increase worldwide including South Africa and these cause a wide range of social, economic and environmental problems. The main concern is the production of microcystins that affect water quality with adverse effects on lake ecology, livestock, human water supply and

\footnotetext{
* Corresponding author: Email: jabulani.gumbo@univen.ac.za; jabulani_gumbo@yahoo.co.uk,Tel:+27 962 8563; Fax: +27 9628597.
} 
recreation (Codd et al., 1997; Nakamura et al., 2003a; Choi et al., 2005). Biological control agents have been isolated from harmful algal blooms and have been implicated in the termination of these HABs (Ashton and Robarts, 1987; Bird and Rashidan, 2001; Nakamura et al., 2003b; Choi et al., 2005).

In the previous study it was observed that predatory bacteria, Bacillus mycoides were responsible for plaque formation on M. aeruginosa lawns (Gumbo et al., 2010). The main objective of this study was to gain insights into interactions between the predatory bacteria B. mycoides and M. aeruginosa cells. Scanning electron microscopy (SEM) was used to assess the morphological changes of the B. mycoides cells on contact with the prey. Transmission electron microscopy (TEM) was used to determine ultrastructural changes that occurred during the interactions between $M$. aeruginosa and B. mycoides. The previous studies of light and electron microscopy studies (Gumbo and Cloete, 2011) and this study formed the basis for the development of a model describing the mechanism of Microcystis lysis.

\section{Materials and methods}

\subsection{Culture of M. aeruginosa}

M. aeruginosa PCC7806 was cultured in $500 \mathrm{~mL}$ Erlenmeyer flasks using modified BG11 medium (Krüger and Eloff, 1977) under shaking incubation $\left(78 \mathrm{rpm}, 25^{\circ} \mathrm{C}\right)$ for $8 \mathrm{~d}$ under continuous light. Two 18W cool white florescent lamps (Lohuis FT18W/T8 1200LM) that were suspended above the flasks provided continuous lighting (2000 lux). The $M$. aeruginosa cell suspensions were used as prey.

\subsection{Culture of B. mycoides B16}

The bacteria $B$. mycoides B16 was either used as a $24 \mathrm{~h}$ culture or lyophilized powder. Fresh bacteria were prepared by inoculation into $100 \mathrm{~mL}$ of one-tenth of Tryptic soy broth (TSB) in a $250 \mathrm{~mL}$ Erlenmeyer flask and shake incubated $\left(128 \mathrm{rpm}, 25^{\circ} \mathrm{C}\right)$ for $24 \mathrm{~h}$ (Di Franco et al., 2002). Lyophilized cells were prepared by centrifugation of fresh cultures $\left(10,000 \mathrm{rpm}, 15 \mathrm{~min}, 25^{\circ} \mathrm{C}\right)$ and freeze dried (Edwards freeze dryer: minus 50 ${ }^{\circ} \mathrm{C}, 2.8 \mathrm{mbar}, 72 \mathrm{~h}$ ). The lyophilized powder was stored at $4{ }^{\circ} \mathrm{C}$ until further use. 


\subsection{Ultrastructural changes in Microcystis cells during lysis after exposure to $B$. mycoides B16}

A $20 \mathrm{~mL}$ M. aeruginosa suspension was exposed to $198.3 \mathrm{mg}$ of lyophilized B. mycoides B16 powder and subjected to shake incubation $\left(78 \mathrm{rpm} ; 25^{\circ} \mathrm{C} ; 2000\right.$ lux continuous light illumination) for $20 \mathrm{~h}$. For the control, $20 \mathrm{~mL} M$ aeruginosa suspension was used and incubated as above. At hourly intervals $1 \mathrm{~mL}$ of treated and control samples were sampled and centrifuged $\left(10,000 \mathrm{rpm}, 10 \mathrm{~min}, 25^{\circ} \mathrm{C}\right)$. The pellet was re-suspended and fixed in $1 \mathrm{~mL}$ of $2.5 \%$ gluteraldehyde in $0.1 \mathrm{M}$ sodium cacodylate buffer at $\mathrm{pH} 6.65$ and stored at $4^{\circ} \mathrm{C}$ until further TEM and SEM analysis.

\subsection{Scanning electron microscopy (SEM)}

Cell suspensions (control and treated) were filtered through a $0.22 \mu \mathrm{m}$ membrane filter and fixed with $2.5 \% \mathrm{v} / \mathrm{v}$ gluteraldehyde in $0.075 \mathrm{M}$ phosphate buffer $(30 \mathrm{~min})$. The membrane filter was washed three times with $0.075 \mathrm{M}$ phosphate buffer (15 min); dehydrated with 50\% ethanol (15 min); 70\% ethanol (15 min); 90\% ethanol (15 min) and three times with $100 \%$ ethanol (15 min). This was followed by critical point drying (BioRad E3000) and gold coating process (Polaron E5200C). The material was then examined in a Joel JSM 840 scanning electron microscope operating at $5.0 \mathrm{kV}$.

\subsection{Transmission electron microscopy (TEM)}

The samples were then fixed with $1 \mathrm{~mL}$ of $2.5 \%$ gluteraldehyde in $0.1 \mathrm{M}$ sodium cacodylate buffer supplemented with $1 \%$ alcian blue (previously filtered through a Cameo acetate $0.22 \mu \mathrm{m}$ syringe filter) for $2 \mathrm{~h}$ at $4{ }^{\circ} \mathrm{C}$. After primary fixation, the samples were centrifuged $\left(10,000 \mathrm{rpm}, 15 \mathrm{~min}, 25^{\circ} \mathrm{C}\right)$ and the pellet re-suspended in $2.5 \%$ gluteraldehyde in $0.1 \mathrm{M}$ sodium cacodylate buffer. This process was repeated three times and the samples were then post-fixed for $1 \mathrm{~h}$ in $1 \% \mathrm{OsO}_{4}$. The samples were then rinsed in $2.5 \%$ gluteraldehyde in $0.1 \mathrm{M}$ sodium cacodylate buffer and dehydrated in an ascending ethanol series [50, 70, 90 and 100\% (thrice)]. 


\section{Results and discussion}

\subsection{Ultrastructural changes in Microcystis cells during lysis after exposure to $B$. mycoides B16}

Transmission electron microscopy observations revealed that the ultrastructural details of Microcystis cells treated with B. mycoides B16 were different from the control. The ultrastructural characteristics of a healthy and normal Microcystis cell are shown in Figure 1(a) and confirmed that of previous studies (Reynolds et al., 1981; Zohary, 1987). The internal structure of a healthy Microcystis consisted of a multilayered cell wall (CW), plasmalemma (P) and storage granules made up of cyanophycin (C) and polyphosphate bodies (PB) and parallel arrays of thylakoid membranes (TH).

After $2 \mathrm{~h}$ of incubation with B. mycoides B16, the internal structure of Microcystis was changed with a distorted cell wall $(\mathrm{CW})$ enclosing the distorted plasmalemma $(\mathrm{P})$ surrounding large glycogen granules (G), large polyphosphate bodies (P.B.) and large thylakoid membranes (TH) (Figure 1b). The Microcystis cells (bacteria treated) shrunk in size in comparison to the controls and scattered intracellular material presumably polyphosphate bodies were found in the external media (evidence of lysed Microcystis cells) (Figure 1c). Between $4 \mathrm{~h}$ to $8 \mathrm{~h}$ a similar lytic action was observed, i.e., distorted Microcystis cell walls and damage of the cell wall membrane and disoriented thylakoid membranes (Figure 2b). After $23 \mathrm{~h}$, the Microcystis control showed evidence of growth as indicated by cell division (Figures 4.10e), whilst the Microcystis (bacteria treated) showed a distorted cell wall with bacteria attached (Figure 2d) and lysed Microcystis cell debris (Figure 2f).

These findings suggest that during physical contact the bacteria released extracellular substances (Daft and Stewart, 1971; Burnham et al., 1981) that damaged the Microcystis cell membrane. Nakamura et al. (2003b) isolated an extracellular substance from $B$. cereus N14, closely related to B. mycoides B16 (von Wintzingerode et al., 1997) that showed lytic activity towards Microcystis. It is possible that a similar extracellular substance produced by B. mycoides B16 may have resulted in cell lysis during this study. 


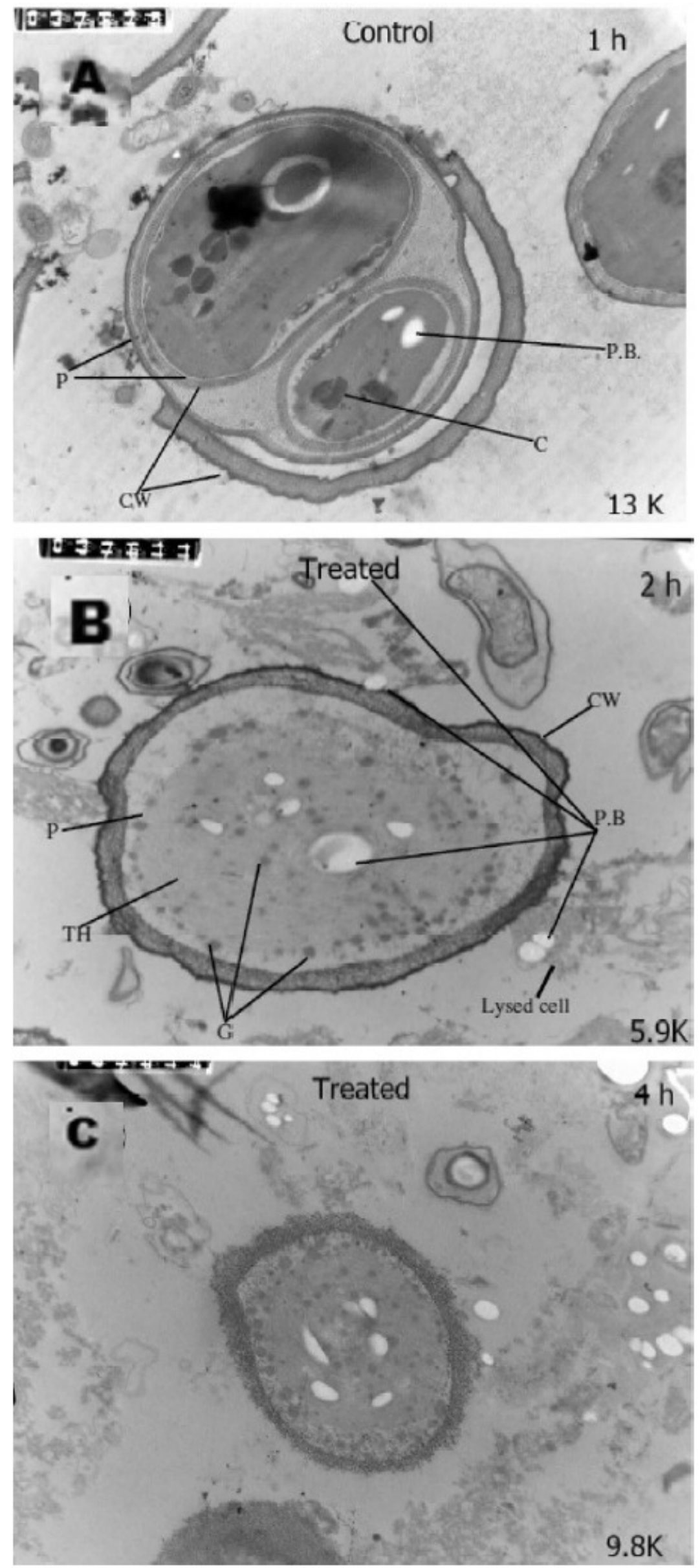


Figure 1: TEM micrographs showing ultrastructural changes in Microcystis cell within 2 $\mathrm{h}$ of incubation with predator bacteria: (A) Control: Healthy Microcystis cell in the process of division, cell wall $(\mathrm{CW})$ and plasmalemma $(\mathrm{P})$, storage granules cyanophycin (C) and polyphosphate bodies (P.B.); (B) Microcystis (bacteria treated); large glycogen granules (G); polyphosphate bodies (P.B.), large thylakoids (TH); (C) After $4 \mathrm{~h}$ incubation, Microcystis cell was smaller due to loss of internal contents and lysis. 

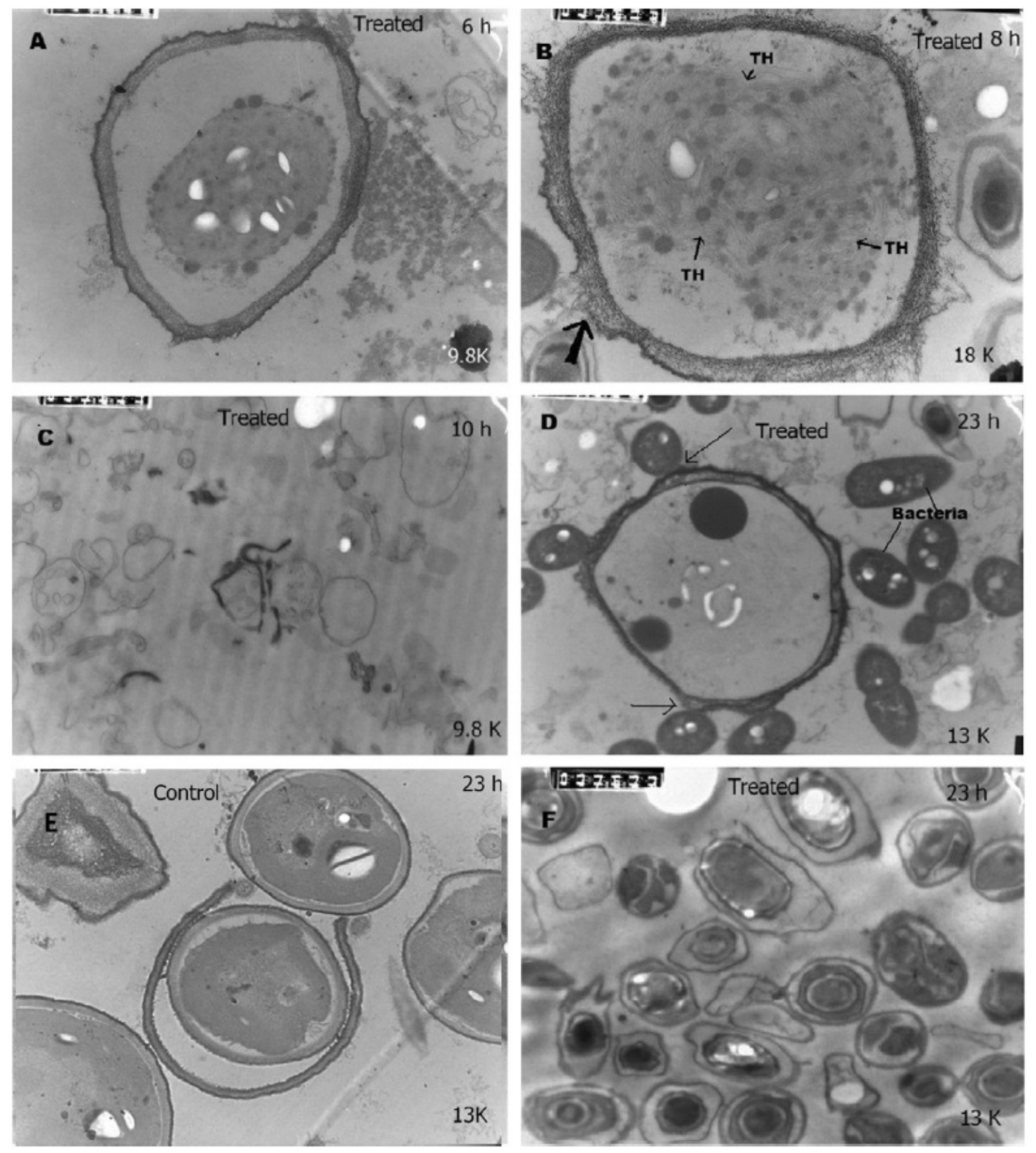

Figure 2: TEM micrographs showing ultrastructural changes in Microcystis cell within $23 \mathrm{~h}$ of incubation with predator bacteria (A-B) Microcystis cell showing signs of distortion after $6 \mathrm{~h}$ and $8 \mathrm{~h}$ in the presence of bacteria. Note damage on cell wall membrane (arrow) and distorted thylakoids (arrow). (C) Lysed Microcystis cells. (D) Bacteria surrounding the Microcystis cell and attacking the cell (arrow); (E) Normal and healthy Microcystis cell after $24 \mathrm{~h}$ and (F) Lysed Microcystis cells after $24 \mathrm{~h}$ after exposure to bacteria.

Previous studies have shown that under experimental conditions of low light irradiance, Microcystis cells had large cyanophycin granules, numerous thylakoid membranes and a large nucleoplasmic area (Canini et al., 2001). On switching to high light conditions, the 
Microcystis produced superoxides to minimise damage to the cell and thylakoid systems and internal organelles were normal. Borbéy et al. (1990) reported similar results, except that the cyanobacteria, when subjected to an adverse external environment such as the presence of predatory bacteria, the cyanobacteria responded by accumulating of storage granules. Polyphosphate bodies, function as a store of phosphorus and appear as spherical inclusions of varying diameters located in the centre of the cell (Jensen, 1968). In our study numerous B. mycoides B16 numbers formed a 'cover or shade' over the Microcystis cells creating conditions of low light irradiance. It was hypothesized that the cyanobacteria then resorted to the production of storage granules like polyphosphates and glycogen. These are for the maintenance of essential processes instead of growth. The other evidence is the expansion of the thylakoid system to capture as much light as possible (Stewart and Alexander, 1971; Schneegurt et al., 1994; Moezelaar and Stal, 1997). The bacteria surrounding to the Microcystis, presumably also released extracellular substances that interfered with the Microcystis photosynthesis system as indicated by the collapse in the plasmalemma and thylakoid membranes that was more evident after $24 \mathrm{~h}$ of bacteria treatment (Figures $4.10 \mathrm{~b}$ and $\mathrm{f}$ ).

Veldhuis et al. (2001) noted that during automortality the last lysis stage involved the degradation of photosynthetic pigments and the reduction in photosynthesis of the phytoplankton. Nakamura et al. (2003b) also observed that during the lytic action by $B$. cereus N14 on Microcystis led to the exudation of photosynthetic pigments to the external media. At the same time the B. mycoides B16 may have derived nutrition from cell contents that leaked out of the Microcystis cells due to the damage of cell wall making it permeable (Figure 2d).

\subsection{Behavioural changes in B. mycoides B16 during the lysis of Microcystis}

Burnham et al. (1984) and Daft et al. (1985) showed that Myxococcus fulvus BG02 exhibited polymorphism: spherules and myxospores, which showed lytic activity against Phormidium luridum and only resorted to the vegetative state when the external environment was nutrient limited. Their mechanism of cyanobacteria lysis was based on the process of spore formation that led to the successful entrapment of cyanobacteria and release of extracellular substances (antibiotics) that targeted the peptidoglycan layer thus enabling M. fulvus BG02 to obtain nutrients. B. mycoides B16 displayed similar 
characteristics changing from single cells to chains during the lysis of Microcystis (Figure $3)$.
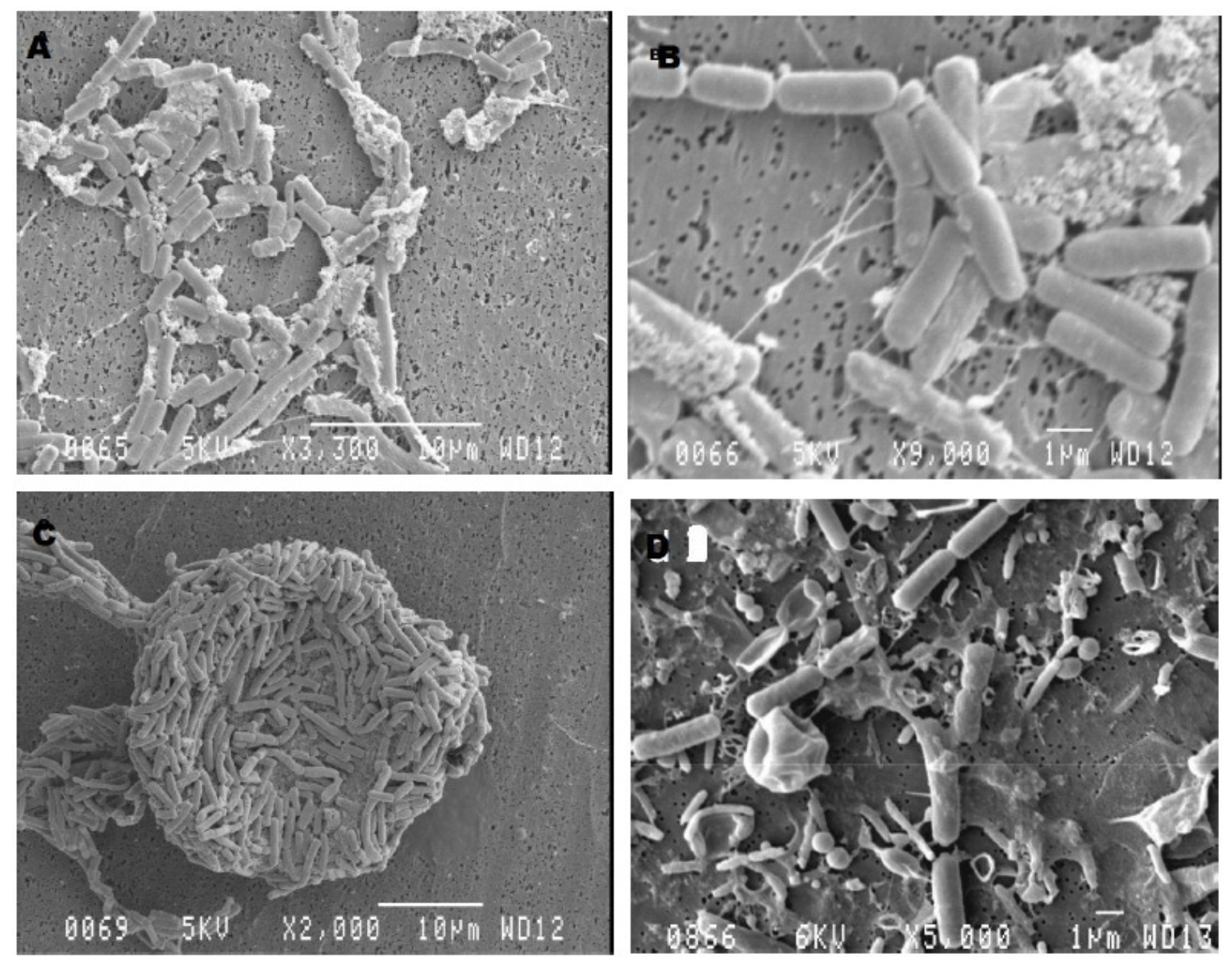

Figure 3: SEM images of Bacillus mycoides B16: (A) individual cells and chains; (B) in chains; (C) multicellular forms and (D) in chains during the Microcystis lysis stage.

B. mycoides B16 switched from single cell to a multicellularity phenotypes which is a characteristics of rhizodal phenotypes of B. mycoides species (Villain et al., 2006). The rhizoidal growth of $B$. mycoides through chain elongation over long distance may be viewed as translocation through the Microcystis algal blooms. Thus the bacteria were able to derive nutrients from the lysis of Microcystis cells during the translocation process. Also the B. mycoides species formed clumps, possible as a survival strategy in the event of nutrient limitations (Villain et al., 2006). It was very difficult to break these clumps except through ultrasonication. Some Bacillus species were reported to revert to spore formation, only germinating and becoming active once the external environment was conducive for growth (Villain et al., 2006). The spore formation state was not observed with $B$. mycoides B16 through the malachite test. 
3.3. The mechanism of lytic action of B. mycoides B16 on Microcystis

The results of this study on the interactions of Microcystis aeruginosa and Bacillus mycoides B16 indicated a series of morphological and ultrastructural changes with the cyanobacteria cell leading to its death. These are summarised in a conceptual model that was developed (Figure 4). 


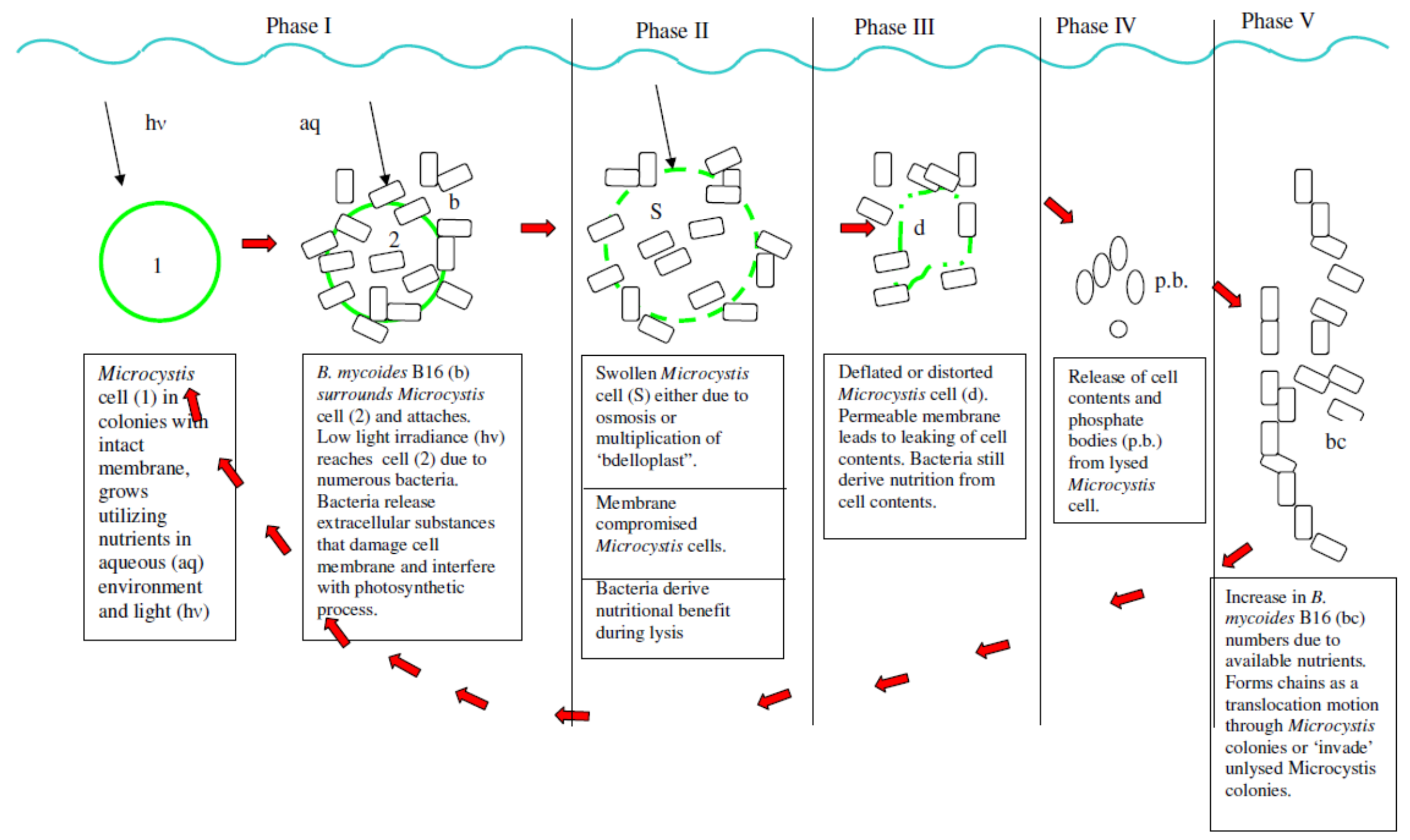

Figure 4: Conceptual model summarizing the fate of a Microcystis cell during lytic action by B. mycoides B16 
We have hypothesised that the first phase in the lysis process is the bacterial attachment onto the Microcystis. At this encounter the large bacteria numbers create conditions of 'shading' over the Microcystis cells, thus creating an environment of low light irradiance. Within $2 \mathrm{~h}$ with insufficient light the following features were observed: accumulation of glycogen, polybetahydroxybutyrate, cyanophycin and expansion of parallel thylakoids membranes. The controls showed normal and healthy Microcystis cells. After $6 \mathrm{~h}$ the cyanobacteria cell wall was distorted, in some cases broken. The thylakoids, light gathering apparatus, was in disarray and probably not functioning as well. The cyanobacteria resorted to use of accumulated granules for survival and not for growth.

The second and third phases are the bacterial release of lytic substances that damage the cyanobacteria cell membrane. In a separate study of Bacillus cereus, closely related to Bacillus mycoides, was found to release an unidentified lytic substance that lysed Microcystis cells (Nakamura et al., 2003a). The study of algicides showed that this was possible as the evidence of Microcystis cell membrane damage was similar to that of the bacterial attack. Swollen cyanobacterial cells were observed during this stage. This was presumably due to osmosis or the presence of Bdellovibrio-like bacteria that multiplied within the cyanobacteria cell. The ultrastructural evidence presented does not support the later hypothesis despite light microscopy studies (wet mounts) detected bacterial movements within the cyanobacteria cell.

The last phase involved the leaking of cyanobacteria cell contents to the external environment indicating cell death. The B. mycoides B16 derived nutrition from the cell contents that leaked out of the Microcystis. An interesting point was the formation of chains by $B$. mycoides B16 cells. It was suggested that the rhizoidal growth of $B$. mycoides through chain elongation over a long distance could be viewed as a translocation through lysed Microcystis algal blooms in search of new prey. 


\section{Conclusions}

There is evidence, which showed that Bacillus mycoides B16 might be an ectoparasite during the lysis of Microcystis cells and exhibit multicellularity forms that are Bdellovibrio-like bacteria during the last stages lysis of Microcystis cells in order to survive an adverse external environment that was nutrient limited. The mechanism of cyanobacterial lysis may involve changes in ultrastructure of Microcystis aeruginosa, possibly affecting energy sources and the photosynthetic system after exposure to bacteria. This may lead to the death of the cyanobacteria after exhaustion of energy sources and loss of nutrients to the predator bacteria, B. mycoides B16.

\section{Acknowledgements}

Financial support for the study came from NRF and University of Pretoria (UP). Mr A Hall, Microanalysis and Microscopy Unit provide technical assistance with electron microscope.

\section{REFERENCE}

Ashton, P.J., Robarts, R.D., 1987. Apparent predation of M. aeruginosa kutz emend elenkin by a saprospira-like bacterium in a hypertrophic lake (Hartbeespoort dam, South Africa). J Limnol Soc South Africa 13, 44-47.

Bird, D.F., Rashidan. K.K., 2001. Role of predatory bacteria in the termination of a cyanobacterial bloom. Microbial Ecol 41, 97-105.

Borbéy, G., Surrnyi, G., Kós, P., 1990. Stress responses of cyanobacteria and the pleiotropic effects of light deprivation. FEMS Microbio Ecol 74, 141-152.

Burnham, J.C., Collart, S.A., Highison, B.W., 1981. Entrapment and lysis of the cyanobacterium Phormidium luridum by aqueous colonies of Myxococcus xanthus PCO2. Arch Microbiol 129, 285-294.

Burnham, J.C., Susan, A.C., Daft, M.J., 1984. Myxococcal predation of the cyanobacterium Phormidium luridum in aqueous environment. Arch Microbio. 137, 220-225.

Canini, A., Leonardi, D., Caiola, M.G., (2001). Superoxide dismutase activity in the cyanobacterium $M$. aeruginosa after surface bloom formation. New Phytol $152,107-116$.

Choi, H-j., Kim, B-h., Kim, J-d., Han, M-s., 2005. Streptomyces neyagawaensis as a control for the hazardous biomass of $M$ aeruginosa (Cyanobacteria) in eutrophic freshwaters. Biol Control 33, 335-343. 
Codd, G.A., Ward, C.J., Bell, S.G., 1997. Cyanobacterial toxins: occurrence modes of action, health effects and exposure routes. Arch Toxicol Suppl 19, 399-411.

Daft, M.J., Stewart, W.D.P., 1971. Bacterial pathogens of freshwater blue green algae. New Phytol 70, 819-829.

Daft, M.J., Burnham, J.C., Yamamato, Y., 1985. Lysis of Phormidium luridum by Myxococcus fulvus in continuous flow cultures. J Appl Bacteriol 59, 73-80.

Gumbo, J.R., Ross G., Cloete, TE., 2010. The Isolation and identification of Predatory Bacteria from a Microcystis algal Bloom. Afri J Biotechnol 9, 663-671.

Gumbo and Cloete, 2011. Light and Electron Microscope Assessment of the Lytic Activity of Bacillus on Microcystis aeruginosa. Afri J Biotechnol, in press.

Jensen, T.E., 1968. Electron microscopy of polyphosphate bodies in blue green alga, Nostoc pruniforme. Arch Mikorobio. 62, 144-152.

Krüger, G.H.J., and Eloff, J.N., 1977. The influence of light intensity on the growth of different $M$ aeruginosa isolates. J Limnol Soc South Africa 3, 21-25.

Moezelaar R., and Stal, L.J., 1997. A comparison of fermentation in the cyanobacterium $M$ aeruginosa PCC7806 grown under a light/dark cycle and continuous light. Eur J Phycol 32, 373-378.

Nakamura, N., Nakano, K., Sugiura, N., Matsumura, M., 2003a. A novel cyanobacteriolytic bacterium, Bacillus cereus, Isolated from a Eutrophic Lake. J Biosci Bioeng 95, 179-184.

Nakamura, N., Nakano, K., Sungira, N., Matsumura, M., 2003b. A novel control process of cyanobacterial bloom using cyanobacteriolytic bacteria immobilized in floating biodegradable plastic carriers. Environ Technol 24, 1569-1576.

Reynolds, C.S., Jaworski, G.H.M., Cmiech, H.A., Leedale, G.F., 1981. On the Annual cycle of the blue green alga $M$ aeruginosa Kutz. Emend. Elenkin. Philos Trans R Soc Lond B Biol Sci 293, 419-477.

Riemann, L., Steward, G.F., Azam, F., 2000. Dynamics of bacterial community composition and activity during a mesocosm diatom bloom. Appl Environ Microbiol 66, 578-587.

Schneegurt, M.A., Sherman, D.M., Nayar, S., Sherman, L.A., 1994. Oscillating behavior of Carbohydrate Granule Formation and Dinitrogen Fixation in the Cyanobacterium Cyanothece sp. Strain ATCC 51142. J Bacteriol 176, 15861597.

Stewart, W.D.P., and Alexander, G., (1971). Phosphorus availability and nitrogenase activity in aquatic blue-green algae. Freshw Biol 1, 389-404. 
Veldhuis, M.J.W., Kraay, G.W., Timmermans, K.R., 2001. Cell death in phytoplankton: correlation between changes in membrane permeability, photosynthetic activity, pigmentation and growth. Eur J Phycol 36, 167-177.

Villain, S., Luo, Y., Hildreth, M.B., Brözel, V.S., 2006. Analysis of the Life Cycle of the Soil Saprophyte Bacillus cereus in Liquid Soil Extract and in Soil. Appl Environ Microbiol 72, 4970-4977.

Von Wintzingerode, F., Rainey, F.A., Kroppenstedt, R.M., Stackebrandt, E., 1997. Identification of environmental strains of Bacillus mycoides by fatty acid analysis and specific 16S rDNA oligonucleotides probe. FEMS Microbiol Ecol 24, 201-209.

Zohary, T., 1987. On the ecology of hyperscum-forming M. aeruginosa in a hypertrophic African lake. Unpublished $\mathrm{PhD}$ Thesis, University of Natal, Pietermaritzburg. 